\title{
Increasing the use of supplemental fibre sources in pulping
}

\author{
by P.A. Watson ${ }^{1}$ and J.V. Hatton ${ }^{1}$
}

The highlights of a recent two-day workshop to address problems of fibre shortages and increasingly high delivered wood costs show that, based on their quality, availability and impact, several supplemental fibre sources can be used effectively in chemical and mechanical pulping. The workshop, held in Vancouver, British Columbia, was hosted jointly by the Pulp and Paper Research Institute of Canada and the Forest Engineering Research Institute of Canada.
Les points saillants d'un récent atelier de deux jours portant sur les problèmes de pénuries de fibre et de coûts sans cess croissants du bois livrés aux usines montrent que, suivant leur qualité, leur disponibilité et leur impact, plusieurs sources supplémentaires de fibre peuvent être utilisées efficacement dans la fabrication de la pâte chimique et mécanique. L'atelier, tenu à Vancouver, ColombieBritannique, était parrainé conjointement par l'Institut canadien de recherches sur les pâtes et papiers et l'Institut canadien de recherches en génie forestier.

\section{Introduction}

Problems of dwindling fibre supplies and increasingly high delivered wood costs in British Columbia and elsewhere in Canada threaten our competitive position in world markets. Over the past two decades, PAPRICAN has evaluated the wood and pulping properties of a wide variety of wood cellulosic sources, and FERIC has acquired significant expertise in extracting and upgrading many of these materials. Last year provided a timely opportunity to focus on the exploitation of a variety of underutilized cellulosic sources. The following describes the potential and limitations of these materials as supplements to more traditional fibre sources.

\section{Utilization of Pin Chips}

Pin chips are defined as those passing a 3/8" RH and retained on a $3 / 16 "$ or $1 / 4$ " RH [Williams classifier]. Alternative definitions include Stalsvets $[-7 \mathrm{~mm} \mathrm{RH},+3 \mathrm{~mm} \mathrm{RH}]$ and Rader [ $-3 \mathrm{~mm}$ slot, $+1.5 \mathrm{~mm}$ slot $]$.

In kraft pulping, it has consistently been shown that yield of pin chips is $97 \%$ that of accept chips set at $100 \%$, and strength of pin chips is $90 \%$ that of accept chips set at $100 \%$ (Hatton 1975).

Accordingly, and as shown in the example (Table 1), increasing the pin chip content from $4.6 \%$ to as much as $10 \%$ neither affects pulp yield nor pulp strength in a measurable way. One additional benefit results from increased pin chip usage. The fill factor of a digester is slightly increased so that pulp production rates also increase.

Theoretically, it is possible to use $7.5-10 \%$ pin chips in a furnish but they must be dispersed uniformly to minimize problems with liquor circulation. The pin chips used must be sound and contain no bark or other contaminants.

\begin{tabular}{|c|c|c|}
\hline Chip furnish & $\begin{array}{l}\text { Pulp yield, relative } \\
\text { to } 100 \% \text { accepts }(\%)\end{array}$ & $\begin{array}{l}\text { Pulp strength, relative } \\
\text { to } 100 \% \text { accepts }(\%)\end{array}$ \\
\hline $\begin{array}{l}4.6 \% \text { pins: } \\
95.4 \% \text { accepts }\end{array}$ & 99.9 & 99.5 \\
\hline $\begin{array}{l}7.5 \% \text { pins: } \\
92.5 \% \text { accepts }\end{array}$ & 99.8 & 99.3 \\
\hline $\begin{array}{l}10 \% \text { pins: } \\
90 \% \text { accepts }\end{array}$ & 99.7 & 99.0 \\
\hline
\end{tabular}

${ }^{1}$ Pulp and Paper Research Institute of Canada, 3800 Wesbrook Mall, Vancouver, BC V6S 2L9.

\section{Discussion}

One $\mathrm{BC}$ pulp mill has been running a trial in which the use of pin chips in the furnish has been increased from $4-4.5 \%$ to $5-6 \%$. The mill is recovering 40 to 60 tons per day more green wood in the form of pins which equates to about 11 tons per day of dry fibre. The mill's target is to use 8 to $10 \%$ pin chips. So far, the mill has not been able to show any loss in pulp strength.

With regard to pulp quality considerations, it was indicated that an uneven digester feed causes more problems with pulp strength than do pin chips.

The question of how pin chips affect the production of mechanical pulps was discussed. It seems that the biggest problem with pin chips is blocking of the resin removal holes in plug screw feeders which causes some carryover of resins. The problem was generally worse in winter than summer.

Pin chips originating from the chipping of roundwood would have a higher juvenile wood content (Hatton 1995) than those from sawmill residual chips. Pin chips also arise from the downsizing of overthick or oversize chips by slicing or conditioning (crushing).

\section{Utilization of Thinnings}

Under normal rotation ages the effect of juvenile wood has been negligible. However, as rotation ages diminish, juvenile wood has become more prevalent in the form of thinnings and toplogs. Juvenile wood has received bad press from lumber producers because of warping and shrinkage in solid wood products (a consequence of the high microfibril angle $\left(25-35^{\circ}\right)$ relative to mature wood $\left(\sim 5^{\circ}\right)$ but it provides many benefits in kraft and mechanical pulping (Hunt and Hatton 1995; Hatton et al. 1995; Hatton and Johal 1996). Juvenile wood in older trees (where it exists in the form of heartwood) contains more extractives, and is less dense and drier, but in thinnings the moisture content is more than $50 \%$. Some comparisons with mature wood follow:

\section{Kraft pulp}

- lower yield for juvenile wood by $1-1.5 \%$; shorter, finer fibres;

- handsheets are denser, smoother, more extensible and stronger in tensile;

- tear index is lower. 


\section{Mechanical pulp}

- requires more energy because of the larger number of thinnerwalled fibres;

- shorter fibres;

- handsheets are less than $10 \%$ weaker in tear and tensile strengths;

- scattering coefficient is vastly superior.

There are, however, many things that are unknown regarding the use of thinnings in Canada. These include the following:

- Impact of thinning on the quality and growth rate of trees in the residual stand

- Impact of the thinning methodology used on the above

- The risk of damaging residual trees depending upon the thinning equipment used

- The age at which thinning should be performed (this presumably depends upon species type and initial stand density)

- The extent of thinning that should be performed (for example, what stand density would be preferable following thinning; what would be the increased risk of windthrow with lower stand densities, etc.?)

- How should thinnings best be processed? (If by an on-site chainflail/delimber/debarker, what minimum bole diameter can be tolerated to minimize breakage and maximize debarking efficiency?)

- Delivered wood costs at the mill gate.

\section{Discussion}

There are three major age classes of thinnings on the west coast of B.C. and, of the 50 to 60 -year-old stands, $35-40 \%$ have been thinned to some extent. Thinning is carried out for fibre recovery and to concentrate growth onto the remaining stems since a given site will fix the same amount of fibre at either 400 or 700 stems ha $^{-1}$. There is also an opportunity to fertilize 10 years before harvest and to prune in conjunction.

Thinning 30-year-old Douglas-fir to 400 stems ha $^{-1}$ will increase the recoverable volume at 80 years compared with a site left at 700 stems ha $^{-1}$ because of reduced mortality in the former case.

The presence of compression wood and knots in thinnings and juvenile wood often results in increased amounts of overthick chips and a less uniform pulp. Fibre length increases with the number of annual rings up to about 30 years.

The current fibre shortage in $\mathrm{BC}$ was predicted to result in an upsurge in thinning.

\section{Hydroelectric Wood}

This is material "drowned" in the artificial lakes formed by hydroelectric power projects and consist of three types of material - always wet, always dry, and wet/dry due to fluctuations in water level (Hatton et al. 1976; Hatton and McGowan 1975). Their characteristics relative to live mature trees follow.

Floating Timber

- Moisture content $>60 \%$

- Bark Content $<0.1 \%$

- Wood is sound

- Relatively easy to extract

- Chips well

- Kraft pulp yield higher by at least $2 \%$, O.D. wood
- Carry extra water around process

- Kraft pulp strength

normal

- No mechanical pulping

done on this material

\section{Discussion}

There was concern expressed over the availability of the type of material, although it was noted that at least two lakes held quantities of both floating and standing timber. The effects of long-term underwater storage on wood and pulp quality were questioned. While there were substantial benefits (see above) in using this material in kraft pulping, the properties of refiner mechanical pulps had not been determined - and probably should be. The question of wood colour also was raised.

\section{Forest Residuals}

\section{Coastal BC}

This material is wood which falls below the utilization specifications set by the $\mathrm{BCMoF}$, i.e. has a high level of decay (Hunt and Hatton 1979) or is below size due to breakage during harvest. This material collects at landings ( $70 \%)$, roadsides and in natural gulleys and draws. Such residuals are $50 \%$ more economic to recover while harvesting operations are still being carried out. The economics also indicate that removal to a central location to use conventional equipment is better than on-site chip processing. One west coast company mixes this material with longer wood to avoid excessive breakage during drum debarking.

\section{$B C$ Interior}

Material typically consists of $10 \mathrm{~cm}$ tops in amounts about $30 \mathrm{~m}^{3} \mathrm{ha}^{-1}$ and $>5 \mathrm{~cm}$ tops in amounts about $80-200 \mathrm{~m}^{3} \mathrm{ha}^{-1}$. There really is not too much material in these classes. The dilemma remains to develop equipment which can debark and chip small material.

\section{Discussion}

The question of upgrading fire-killed wood by removing carbon was raised. Chain flails might do the job; Australia developed high pressure water jet technology in the 80 s to treat huge quantities of fire-killed wood.

\section{Woodyard Residues}

On average, about $5 \%$ of the total wood handled at dryland sortyards and sawmill woodyards ends up as residues. This is a function of the yard, its equipment and its practices. The residues, which contain a large amount of inorganic material, are either burnt or landfilled. This material needs to be better utilized as a resource so it must be kept separate, and clean - the number one issue. The diversity of species, particularly on the $\mathrm{BC}$ coast, is seen as an impediment to utilization. This material could find a specific end use in corrugating medium for example.

\section{Decadent Wood}

Decay, rot and stain are all different phenomena. In standing live trees white rot, brown rot and insect-affected wood are the three common causes of decadence in wood. White and brown rots affect the heartwood while, in the initial stage, insect attack results in discolouration of the sapwood making this mate- 


\begin{tabular}{lcccc}
\hline Table 2. Fibre Losses through the Kraft Process & & & \\
\hline Area & Mill 1 (1300tpd) (\%) & Mill 2 (1000tpd) (\%) & Mill 3 (750tpd) (\%) & Mill 4 (630tpd) (\%) \\
\hline Chip screening & 4.5 & $2-3$ & 2.5 & $3-4$ \\
Knotter/Brownstock screen & 0.25 & 0.5 & 0.2 & 0.4 \\
Bleach cleaners & 0.1 & 0.2 & $\sim 0.1$ & 0.24 \\
Pulp machines & $\sim 0$ & $\sim 0$ & 39 & $\sim 0$ \\
Bleached yield (\% of wood) & 40 & 41 & 0.1 & $?$ \\
Spills & 0.2 & $\sim 0$ & $6-7$ & 5 \\
Total fibre loss/day (tonnes) & $9-10$ & 6 &
\end{tabular}

rial suitable only for kraft pulping. Methods to assess decay include visual appearance, fungal identification and chemical testing (usually $1 \%$ caustic solubility). Screening will remove most of the decayed material. Decayed wood usually produces a lower yield of lower strength pulp - especially brown rot-decayed material. The effect of bleaching sound and decayed wood pulp of similar kappa number has not been determined.

Decadent cedar and hemlock in the Columbia, North Thompson and Nakusp areas of BC are $50 \%$ chippable; there are also significant volumes in the Castlegar region. There is a considerable body of literature on the pulping characteristics of this material (Hatton 1978, 1979, 1981; Hunt 1978a; 1978b; 1978c; 1978d).

\section{Breakout Sessions}

The workshop concluded with two breakout sessions; the first focussed on changes needed to accommodate variations in fibre quality, the second quantified fibre losses during the production of kraft pulps.

\section{Woodyards/Woodrooms of the Future}

This session was designed to discuss changes in mill practice which must be made to accommodate the changing chip resource. Inventory management is seen as a key area for immediate improvement as are the attitudes of the chip suppliers. Currently chips are sold to the highest bidder with little or no assessment of quality. The chip pile, although often constrained by space, is another area worth serious consideration on a mill-by-mill basis. To assist with current practices, the ideal solution would be to develop an on-line chip grading technology which can assess all of the fundamentally important chip parameters prior to entering the digester.

\section{Key Outcomes}

- better inventory control over both species and chips is needed

- better chip quality criteria is needed

- supplier education

- chip age, juvenile/mature wood determination

- species identification

- degree of chip deterioration

- sampling methodology

- economic consequences of chip quality

- satellite or portable chipping is an important method to ensure species segregation

- need to be able to determine which species form the chip furnish

- elsewhere in the world competitors are making strides to catch and overtake the quality of $\mathrm{BC}$ fibres; hence, product-targeted fibre lines are needed.

We need a better fundamental knowledge of our fibrous raw materials to allow us to develop new product opportunities from our unique resource. The conclusions reached here are applicable Canada wide.

\section{Fibre Losses through the Kraft Pulping Process}

There are measurable losses in mill fibre lines from chip screening through to the pulp machine. That is fibre paid for but somehow lost. Key areas of loss were identified (Table 2).

\section{Key Outcomes}

- most mills considered that pin chips could be viably recovered, i.e. increased from 5 to $10 \%$ of the pulp furnish

- most mills considered that some of the brown stock screen/ knotter rejects could be recovered ( $50 \%)$

- bleached cleaner reject recovery was already very high

- from a process point of view all mills were very similar.

\section{Conclusions and Recommendations}

The following was concluded after two days of presentations and discussions of mill and field experiences.

- Smaller wood particles such as pin chips can be used in amounts up to $10 \%$ without affecting pulp yield or quality.

- The use of juvenile wood in the form of thinnings is satisfactory for pulping, and its use will increase. As a major silvicultural option in forest management, thinning is "here to stay".

- The benefits of using some forms of drowned (hydroelectric) wood in kraft pulping will foster increased use of a fibre source with uncertain availability.

- Many types of decadent wood can be used successfully in amounts up to $10 \%$ at mills making chemical and mechanical pulps.

- Upgrading of forest residuals and woodyard residues by Paprifer ${ }^{\mathrm{TM}}$ could provide increasing amounts of chips clean enough for most pulping processes.

- Woodyards and woodrooms must be designed to facilitate the concept of product-targeted fibre lines.

- Fibre losses in kraft pulping can be reduced by recovering more in chips and screen/knotter rejects.

It is recommended that pulp producers increase their use of these supplemental fibre sources wherever feasible, and wherever final product quality is not jeopardized. There are environmental as well as cost benefits in so doing.

\section{Acknowledgements}

To all the discussion leaders and participants for their invaluable contributions.

\section{References}

Hatton, J.V. 1975. Quality and kraft pulping characteristics of residual chips. Tappi 58(2): 110-114.

Hatton, J.V. 1978. Debarking wood losses and chip quality of dead- 
wood: Spruce budworm-killed softwoods in New Brunswick. Tappi 61(12): 43-46.

Hatton, J.V. 1979. Can budworm-killed wood be used in pulping? Pulp and Paper Canada 80(11): T365-370.

Hatton, J.V. 1981. Utilization of dead wood in pulping: Current studies on the processing of spruce budworm-killed balsam fir. Pulp and Paper Canada 82(3): T95-102.

Hatton, J.V. 1995. Pulping and papermaking properties of managed second-growth forests. Proceedings, Tappi Pulping Conference, Chicago, IL, p. 673-681.

Hatton, J.V. and W.M. McGowan, 1975. Flooded timber strength and utilization. Information Report VP-X-150 [Available from Forintek Canada West Library, Vancouver, BC].

Hatton, J.V. and S.S. Johal. 1996. Mechanical pulping of commercial thinnings of six softwoods from New Brunswick. Preprints, Annual Meeting, Technical Section CPPA, Montreal, QC, B25-35.

Hatton, J.V., J.L. Keays, H. Waelti. 1976. Salvaged hydroelectric wood yields high quality chips for pulping. Pulp and Paper 50(6): 90-91.
Hatton, J.V., W.Y. Gee, K. Hunt. 1995. Kraft pulping of commercial thinnings of six softwoods from New Brunswick. Preprints, 1995 Spring Conference, Technical Section CPPA, Pacific Coast and Western Branches, Whistler, BC. 9 p.

Hunt, K. 1978a. Chipping western hemlock decayed by white-rot fungi. Pulp and Paper Canada 79(6): T192-193.

Hunt, K. 1978b. Pulping western hemlock decayed by white-rot fungi. Pulp and Paper Canada 79(6): T194-198.

Hunt, K. 1978c. Kraft pulping of decayed wood: Western red cedar and alpine fir. Pulp and Paper Canada 79(7): T229-234.

Hunt, K. 1978d. How rot-decayed wood affects chipping and kraft pulping. Pulp and Paper Canada 79(8): T264-267.

Hunt, K. and J.V. Hatton. 1979. Predicting the kraft pulping behaviour of decayed pulpwood. Pulp and Paper Canada 80(3): T72-74. Hunt, K. and J.V. Hatton. 1995. Specific gravity and chemical properties of wood from commercial thinnings of six species of softwoods grown on plantations in New Brunswick. Preprints, Annual Meeting, Technical Section CPPA, Montreal, QC, A11-18. 